\title{
Pembentukan Kokristal Asam Usnat - N-Methyl-D-Glucamine dengan Metode Penguapan Pelarut dan Pengaruhnya terhadap Penurunan Interleukin-8 pada Tikus Inflamasi
}

(Cocrystal of usnic acid- $n$-methyl-d-glucamine using solvent evaporation technique and the effect on decreasing interleukin-8 levels in inflamed rat)

\author{
Muthia Fadhila, Salman Umar, \& Erizal Zaini* \\ Fakultas Farmasi Universitas Andalas, Jl. Limau Manis, Kec. Pauh, Kota Padang, Sumatera Barat 25163
}

\begin{abstract}
The objective of the research was to prepare the cocrystal of usnic acid-N-methyl-D-glucamine in order to increase solubility, dissolution rate, and decrease IL-8 levels in rats with inflammation. Cocrystal was prepared with a ratio of 1:1 equimolar by a solvent evaporation method using etanol. Characterizations were conducted using Powder X-ray diffraction (PXRD), Differential Scanning Calorimetry (DSC), infrared spectroscopy (FT-IR), and Scanning Electron Microscopy (SEM). The solubility test, dissolution rate test, and determination of interleukin-8 (IL-8) levels in rats were also performed. $\mathrm{CO}_{2}$ free distilled water was used as a media in the solubility test. Meanwhile, $\mathrm{CO}_{2}$ free distilled water with $0.25 \% \mathrm{w} / \mathrm{v}$ Sodium Lauryl Sulphate (SLS) were used as the media for dissolution rate studies. Both tests were conducted using a UV-Vis spectrophotometer. The determination of IL-8 levels in rat was performed by using an ELISA method. Powder X-ray Diffraction (PXRD) diffractogram showed a new peak compared to diffraction peaks of each component and physical mixture that confirmed the formation of cocrystal, and peak intensity decreased that shown formation of eutectic mixture. The appearance of the DSC thermogram from cocrystal showed different endothermic peaks for both constituent components. The FT-IR spectrum of cocrystal showed a shift of the wave number spectrum compared to pure usnic acid and N-methyl-D-glucamine. Microscopic analysis by SEM showed a change of crystal morphology. The solubility and dissolution rate of cocrystal increased significantly $(p<0.05)$ by 24 and 23 times compared to the pure usnic acid. Cocrystal could reduce IL-8 levels in rats with inflammation equivalent to acetosal $(P<0.05)$. This study concludes, that cocrystal of usnic acid- $\mathrm{N}$ methyl-D-glucamine can enhance solubility and dissolution rate, and decrease IL-8 levels in rats with inflammation.
\end{abstract}

Keywords: usnic acid; N-methyl-D-glucamine; cocrystal; solubility; dissolution rate; interleukin-8.

ABSTRAK: Pada penetitian ini pembentukan kokristal asam usnat-N-methyl-D-glucamine bertujuan untuk meningkatkan kelarutan dan laju disolusi asam usnat serta uji efektivitasnya dalam kadar IL-8 pada tikus inflamasi. Kokristal asam usnat-N-methyl-Dglucamine dibuat dengan perbandingan 1:1 ekuimola dengan metode penguapan pelarut menggunakan etanol. Karakterisasi sampel dilakukan dengan difraksi sinar-X, Differential Scanning Calorimetry (DSC), Fourier Transform Infrared (FTIR), dan Scanning Electron Microscopy (SEM). Evaluasi kokristal yang dilakukan mencakup uji kelarutan, uji laju disolusi, dan penentuan kadar interleukin-8 (IL-8) pada tikus inflamasi. Uji kelarutan dilakukan menggunakan pelarut air suling bebas $\mathrm{CO}_{2}$ sedangkan uji laju disolusi menggunakan media air suling bebas $\mathrm{CO}_{2} 0.25 \%(\mathrm{~b} / \mathrm{v})$ sodium lauril sulfat (SLS), kedua larutan uji dianalisis menggunakan spektrofotometer UV-Vis. Pemeriksaan IL-8 tikus inflamasi menggunakan metode ELISA. Hasil karakterisasi difraksi sinar-X menunjukkan profil difraktogram yang berbeda dari komponen penyusun yang mengindikasikan terbentuknya fase kokristal. Hasil termogram DSC menunjukkan adanya puncak endotermik baru yang berbeda dengan kedua komponen penyusun. Spektrum FT-IR menunjukkan terjadinya pergeseran bilangan gelombang pada spektrum kokristal dibandingkan spektrum asam usnat dan $\mathrm{N}$-methyl-D-glucamine. Analisis SEM menunjukkan perubahan morfologi partikel. Kelarutan dan laju disolusi kokristal meningkat secara signifikan $(P<0,05)$ sebanyak 24 kali dan 23 kali dibandingkan dengan senyawa asam usnat murni. Kokristal dapat menurunkan kadar IL-8 pada tikus inflamasi yang setara dengan aktivitas antiinflamasi asetosal $(P<0,05)$. Disimpulkan bahwa koristal asam usnat - N-methyl-D-glucamine dapat meningkatkan kelarutan, laju disolusi, dan menurunkan kadar IL-8 tikus inflamasi.

Kata kunci: asam usnat; N-methyl-D-glucamine; kokristal; kelarutan; laju disolusi; interleukin-8.

\section{Pendahuluan}

Asam usnat adalah metabolit sekunder dari Usnea sp yang merupakan turunan dibenzofuran. Sejak isolasi pertama dilakukan pada tahun 1844 asam usnat(2,6-diacetyl7,9-dibydroxy-8,9b-dimetbyl-1,3(2H,9bH)-dibenzo-furandione) menjadi metabolit lichen yang paling banyak diteliti dan tersedia secara komersial [1,2]. Asam usnat secara organoleptis berbentuk kristal kuning padat [3,4] yang memiliki nilai koefisien partisi $(\log$
Article history

Received: 19 Jan 2019 Accepted: 05 April 2020 Published: 30 April 2020

Access this article

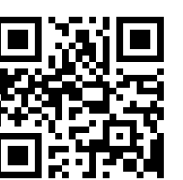


P) 2,88 [5]. Kelarutan asam usnat pada suhu $25^{\circ} \mathrm{C}$ yang dilarutkan dalam pelarut air tergolong rendah yaitu < $0,01 \mathrm{~g} / 100 \mathrm{~mL}$ [3]. Senyawa ini dikategorikan kelas dua berdasarkan Biopharmaceutical Classification System (BCS) dengan kelarutan rendah namun permeabilitas yang tinggi [6].

Ada sejumlah metode yang dapat digunakan untuk meningkatkan kelarutan obat seperti pengurangan ukuran partikel, pembentukan garam, kompleks inklusi dengan siklodekstrin, liposom, amorfisasi, pembentukan kokristal, dan dispersi padat [7]. Salah satu metode yang menarik dan sederhana yang akhir-akhir ini sering dikembangkan untuk meningkatkan kelarutan dan bioavailabilitas obat yang rendah adalah teknik kokristalisasi. Kokristal merupakan suatu kompleks kristal yang terdiri dari dua atau lebih konstituen molekul netral yang terikat bersama dalam kisi kristal melalui interaksi nonkovalen (yang sering digunakan adalah ikatan hidrogen). Metode kokristalisasi dibagi menjadi dua yaitu metode penggilingan dan metode pelarutan [8].

Peningkatan kelarutan obat dengan metode kokristalisasi telah banyak dilakukan dan telah terbukti keberhasilannya. Salah satu diantaranya yaitu kokristal ibuprofen - nikotinamida yang dapat meningkatkan kelarutan dan laju disolusi ibuprofen [9]. Penelitian kokristalisasi asam usnat dengan koformer yang berbeda yaitu 4-Aminopiridin dan Piperazin mendapatkan hasil positif yang meningkatkan kelarutan asam usnat $[10,11]$.

Pada penelitian ini N-methyl-D-glucamine digunakan sebagai koformer untuk membentuk kokristal asam usnat. $\mathrm{N}$-methyl-D-glucamine mempunyai nama kimia 1-deoxy1-(methylamino)-D-glucitol merupakan basa organik yang digunakan sebagai agen pengatur $\mathrm{pH}$ dan peningkat kelarutan. N-methyl-D-glucamine sering digunakan pada formulasi sediaan parenteral dan tergolong tidak toksik sebagai eksipien [12].

Penelitian kokristalisasi asam usnat dengan koformer $\mathrm{N}$-methyl-D-glucamine telah pernah dilakukan menggunakan metode grinding [13], namun belum berhasil membentuk fase kristalin baru. Karenanya, penelitian ini merupakan lanjutan dan modifikasi penelitian tersebut dengan menggunakan metode penguapan pelarut. Tujuannya adalah untuk meningkatkan kelarutan dan laju disolusi asam usnat dilanjutkan dengan penentuan kadar IL-8 pada tikus yang mengalami inflamasi.

\section{Metode Penelitian}

\section{Bahan}

Asam usnat (Laboratorium Kimia Bahan Alam Universitas Andalas, Indonesia), N-methyl-D-glucamine (Sigma-aldrich, USA), kloroform pro analysis (Merck, USA), metanol pro analysis (Merck, USA), etanol pro analysis (Merck, USA), sodium lauryl sulfate (Bratachem, Indonesia), air suling bebas $\mathrm{CO}_{2}$, rat IL-8 ELISA kit (fine test), karagen, etanol $70 \%, \mathrm{Na}-\mathrm{CMC} 1 \%, \mathrm{NaCl} 0,9 \%, \mathrm{NaOH}$ $0,1 \mathrm{~N}$, dan asetosal.

Pembuatan Kokristal Asam Usnat - N-methyl-Dglucamine dengan Metode Pelarutan

Asam usnat dan N-methyl-D-glucamine (yang telah dibasahi air) dicampur dengan perbandingan 1:1 ekuimol ar (0,861 g: 0,488 g). Campuran kedua zat ditambahkan 200 $\mathrm{mL}$ etanol sampai kedua zat terlarut sempurna. Campuran diaduk selama 1 jam dengan bantuan stirrer, kemudian didiamkan hingga kering selama 3 hari pada suhu kamar $\left(27^{\circ} \mathrm{C} \pm 0,5^{\circ} \mathrm{C}\right)$. Kokristal yang terbentuk disimpan dalam wadah tertutup rapat dan dimasukkan ke dalam desikator.

\section{Analisis Difraksi Sinar - X}

Analisis difraksi sinar-X serbuk sampel dilakukan pada suhu ruang dengan menggunakan difraktometer tipe RINT-2500 (Rigaku, Jepang). Kondisi pengukuran sebagai berikut: target logam $\mathrm{Cu}$, filter $\mathrm{K} \alpha$, voltase 45 $\mathrm{kV}$, arus $40 \mathrm{~mA}$, analisis dilakukan pada rentang 2 theta $5^{\circ}-35^{\circ}$. Sampel diletakkan pada sampel holder (kaca) dan diratakan untuk mencegah orientasi partikel selama penyiapan sampel. Analisis dilakukan untuk asam usnat, $\mathrm{N}$-methyl-D-glucamine, dan kokristal asam usnat - N-methylD-glucamine.

Tabel 1. Pengelompokan hewan uji

\begin{tabular}{clcl}
\hline No & Kelompok & Jumlah & Perlakuan oral \\
\hline 1. & Kontrol positif & 5 & Diberikan suspensi Na-CMC $1 \%$ \\
2. & Pembanding & 5 & Diberikan suspensi asetosal $9 \mathrm{mg} / 200 \mathrm{~g} \mathrm{BB}$ \\
3. & Asam usnat murni $50 \mathrm{mg} / \mathrm{kg} \mathrm{p.o}$ & 5 & Diberikan suspensi asam usnat murni $50 \mathrm{mg} / \mathrm{kg}$ p.o \\
4. & Kokristal asam usnat- N-Methyl-D-glucamine $50 \mathrm{mg} / \mathrm{kg} \mathrm{p.o}$ & 5 & Diberikan suspensi kokristal asam usnat setara $50 \mathrm{mg} / \mathrm{kg}$ p.o \\
\hline
\end{tabular}




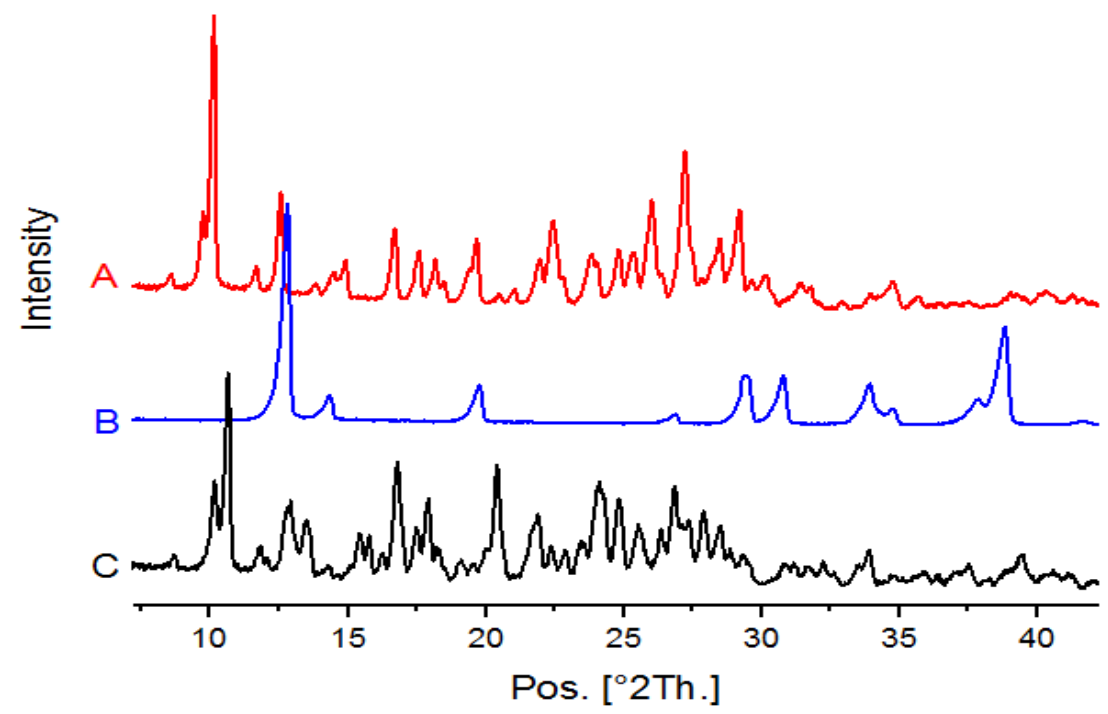

Gambar 1. Difraktogram sinar-X gabungan (a) asam usnat, (b) N-methylD-glucamine, (c) kokristal

Analisis Differential Scanning Colurimetry (DSC)

Analisis termal sampel dilakukan dengan menggunakan alat DSC Setaram. Alat DSC diprogram pada rentang suhu $30^{\circ} \mathrm{C}$ sampai $250^{\circ} \mathrm{C}$ dengan kecepatan pemanasan $10^{\circ} \mathrm{C}$ per menit. Analisis dilakukan pada sampel asam usnat, N-methyl-D-glucamine, dan kokristal asam usnat-N-metbyl-D-glucamine.

\section{Analisis Scanning Electron Microscopy (SEM)}

Sampel serbuk diletakkan pada sample holder alumunium dan dilapisi dengan emas. Sampel kemudian diamati pada berbagai perbesaran alat SEM Jeol tipe JSM-6360LA. Voltase diatur pada $20 \mathrm{kV}$ dan arus $12 \mathrm{~mA}$. Analisis dilakukan untuk asam usnat, N-methyl-D-glucamine, dan kokristal asam usnat - N-methyl-D-glucamine.

\section{Analisis Fourier Transform Infrared (FTIR)}

Sampel diukur dengan alat spektroskopi inframerah tipe Thermo Scientific yang dilakukan dengan mendispersikan sampel pada plat $\mathrm{KBr}$ yang dikempa dengan tekanan tinggi (penekan hidrolik). Sampel yang dianalisis adalah asam usnat, N-methyl-D-glucamine, dan kokristal asam usnat - N-methyl-D-glucamine. Spektrum serapan direkam pada bilangan gelombang 400$500 \mathrm{~cm}^{-1}$. Dari analisis ini diharapkan masing-masing formula menunjukkan puncak transmitan pada bilangan gelombang yang sama dengan asam usnat murni, dan hasil perbandingan dapat terlihat dari hasil spektrum IR yang menunjukkan hubungan bilangan gelombang $\left(\mathrm{cm}^{-1}\right)$ dengan $\%$ transmittan.

Tabel 2. Intensitas puncak spesifik kokristal pada difraktogram sinar-X

\begin{tabular}{cccc}
\hline \multirow{2}{*}{ Posisi $\left(2^{\circ} \mathbf{\theta}\right)$} & \multicolumn{3}{c}{ Intensitas puncak } \\
\cline { 2 - 4 } & Asam usnat & N-methyl-D-glucamine & Kokristal \\
\hline 8,86 & 1011 & 20817 & 778 \\
10,13 & 9468 & 1257 & 2144 \\
12,55 & 3197 & 1137 & 1052 \\
12,91 & - & - & 1900 \\
22,45 & 2556 & 764 & 982 \\
\hline
\end{tabular}




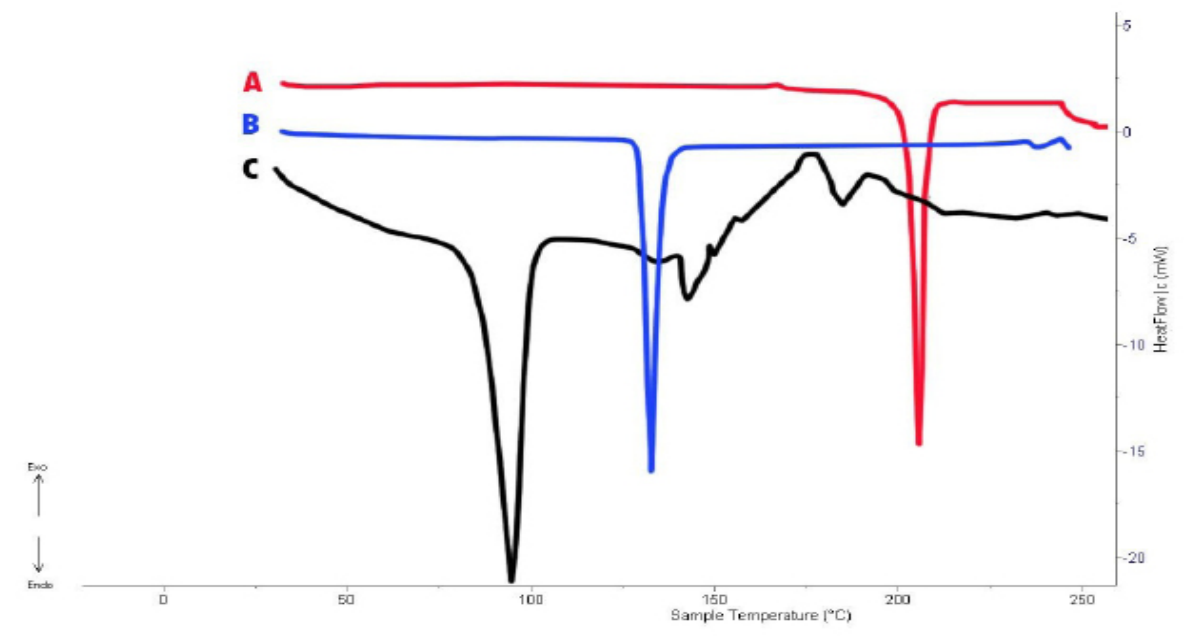

Gambar 2. Termogram DSC gabungan (a) asam usnat, (b) N-methyl-D-glucamine, dan (c) kokristal

\section{Uji Kelarutan}

Uji kelarutan dilakukan pada asam usnat dan kokristal asam usnat - N-methyl-D-glucamine yang dibuat menjadi larutan jenuh dengan menggunakan air suling bebas $\mathrm{CO}_{2}$ sebanyak $100 \mathrm{~mL}$. Sampel yang setara dengan $15 \mathrm{mg}$ asam usnat dilarutkan dalam erlemeyer $100 \mathrm{~mL}$, kemudian dikocok dengan orbital shaker selama 24 jam pada suhu $25^{\circ} \mathrm{C}$. Selanjutnya sampel disaring dengan saringan 0,45 $\mu \mathrm{m}$ (Whatman filter paper) lalu dihitung kadar asam usnat terlarut dengan menggunakan spektrofotometri UV-Vis tipe Shimadzu UV-1700 pada panjang gelombang serapan maksimum.

\section{Uji Laju Disolusi}

Penetapan profil disolusi dilakukan terhadap asam usnat dan kokristal asam usnat - N-methyl-D-glucamine dengan menggunakan alat uji disolusi SR8 Plus Dissolution Test Station Hanson Virtual Instrument, tipe dayung dengan kecepatan $50 \mathrm{rpm}$. Labu diisi dengan media disolusi air suling bebas $\mathrm{CO}_{2}$ ditambah $0,25 \% \mathrm{~b} / \mathrm{v}$ sodium lauril sulfat (SLS) sebanyak $900 \mathrm{~mL}$ dan diatur suhu pada $37 \pm 0,5^{\circ} \mathrm{C}$. Serbuk sampel setara dengan $10 \mathrm{mg}$ asam usnat dimasukkan ke dalam cangkang kapsul. Setelah suhu tersebut dicapai, kapsul dimasukkan ke dalam labu dan alat diputar dengan kecepatan $50 \mathrm{rpm}$. Larutan di dalam labu dipipet sebanyak $5 \mathrm{~mL}$ pada menit ke-5, 10, 15, 30, 45,

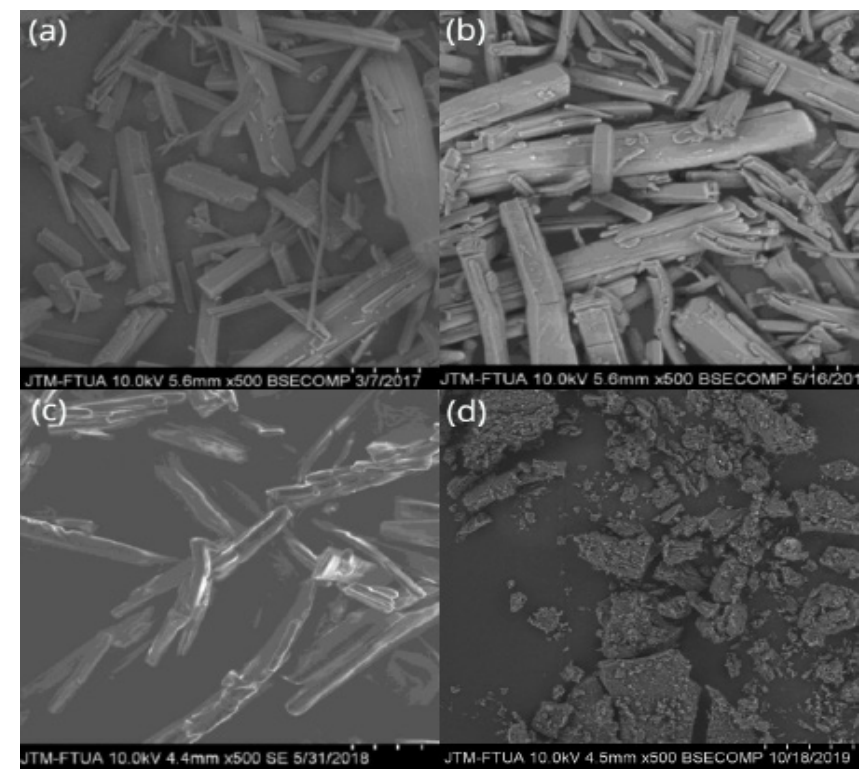

Gambar 3. Morfologi (SEM) (a) asam usnat, (b) N-Metbyl-D-

Glucamine, (c) campuran fisik, (d) kokristal 


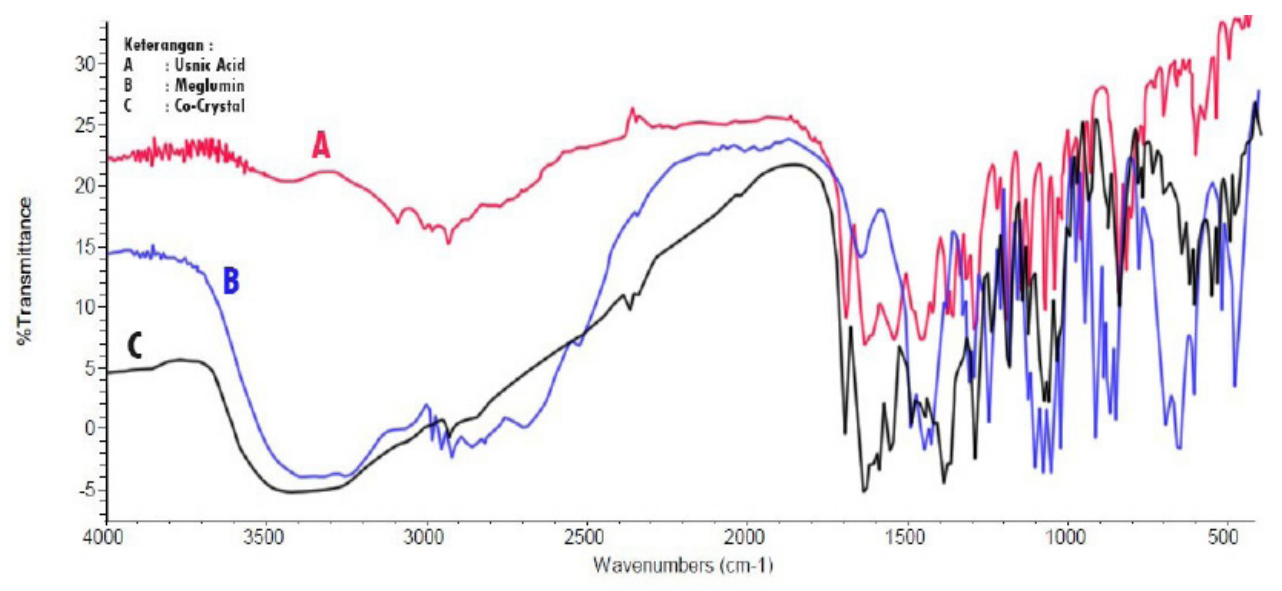

Gambar 4. Spektrum FT-IR gabungan (a) asam usnat, (b) N-Methyl-D-Glucamine, (c) kokristal

dan 60. Pada setiap pemipetan, media yang diambil diganti dengan media disolusi dengan volume dan suhu yang sama saat pemipetan. Masing-masing larutan yang dipipet dimasukkan dalam labu ukur dan diuji menggunakan spektrofotometri UV-Vis dengan blangko air suling bebas $\mathrm{CO}_{2}$ dengan $0,25 \% \mathrm{w} / \mathrm{v}$ SLS pada panjang gelombang serapan maksimum.

\section{Hewan Uji}

Hewan yang digunakan dalam penelitian ini adalah tikus putih jantan galur Wistar umur 2-3 bulan dengan berat badan \pm 200 gram. Semua prosedur sudah mendapat persetujuan dari komite etik penelitian Fakultas Kedokteran Universitas Andalas dengan nomor 554/KEP/FK/2019.

\section{Penentuan Kadar Interleukin-8}

Hewan uji dipuasakan selama 18 jam sebelum perlakuan dan air minum tetap diberikan selama pengamatan. Hewan uji ditimbang bobotnya, dikelompokkan secara acak $(n=5)$ (Tabel 1). Lutut tikus diusap dengan etanol 70\% lalu injeksikan 0,2 mL larutan karagenan 1\%. Larutan suspensi yang sudah disiapkan diberikan kepada hewan uji secara oral (1 jam setelah induksi). Pengambilan darah tikus inflamasi pada vena mata sebanyak 2-2,5 mL pada menit ke 60. Darah didiamkan 5 menit dan dilakukan pemisahan dengan sentrifugasi pada kecepatan 4000 rpm selama 15 menit, selanjutnya dilakukan pemisahan serum dari komponen darah lainnya. Kadar IL-8 diukur dengan menggunakan metode ELISA (enzyme-linked immunosorbent assay) pada panjang gelombang $450 \mathrm{~nm}$.

\section{Analisis Statistik}

Data hasil uji kelarutan, efisiensi disolusi, persentase terdisolusi pada menit ke 60, dan kadar IL-8 pada tikus inflamasi dianalisis secara statistik dengan ANOVA satu arah dengan menggunakan SPSS versi 22 (IBM, USA).

\section{Hasil dan Diskusi}

Berdasarkan hasil analisis difraksi sinar-X ( $\underline{\text { Gambar }}$ 1), difraktogram padatan kokristal asam usnat-N-methylD-glucamine memiliki fase kristalin baru (Tabel 2) yaitu pada posisi $2 \theta 12,91$ dengan intensitas puncak 1900 unit. Hasil intensitas puncak interferensi difraksi sinar-X menunjukkan penurunan derajat kristalinitas pada posisi $2 \theta 8,86$ dengan intensitas puncak asam usnat 1011 unit,

Tabe1 3. Perbandingan bilangan gelombang asam usnat, N-Metbyl-D-Glucamine, dan kokristal

\begin{tabular}{clccc}
\hline & Sampel & \multicolumn{3}{c}{ Bilangan gelombang $\left(\mathbf{c m}^{-1}\right)$} \\
\cline { 3 - 5 } No & & N-H & C-H & C=0 \\
\hline 1 & Asam ssnat & - & 2931,65 & 1691,60 \\
2 & N-methyl-D-glucamine & 3331,80 & 2919,05 & - \\
3 & Kokristal & 3424,00 & 2927,10 & 1697,90 \\
\hline
\end{tabular}


Tabel 4. Hasil uji kelarutan asam usnat dalam air suling bebas $\mathrm{CO}_{2},(n=3)$

\begin{tabular}{lcc}
\hline \multicolumn{1}{c}{ Sampel } & $\begin{array}{c}\text { Kadar terlarut rata-rata }(\mathbf{m g} / \mathbf{1 0 0} \mathbf{~ m L}) \pm \\
\text { standar deviasi (SD) }\end{array}$ & Peningkatan kelarutan \\
\hline Asam usnat murni & $0,256 \pm 0,002$ & - \\
Campuran fisik & $3,654 \pm 0,210$ & 14,291 \\
Kokristal & $6,338 \pm 0,101$ & 24,792 \\
\hline
\end{tabular}

N-metbyl-D-glucamine 20817 unit, dan kokristal 778 unit, ini menunjukkan konglomerasi kedua fase kristal dalam keadaan padat atau disebut sebagai campuran eutektik sederhana [14]. Pada penelitian sebelumnya, kokristal asam usnat memiliki pola difraksi yang sama dengan zat penyusunnya sehingga dapat disimpulkan kokristal tidak menghasilkan fase kristalin baru [13].

Analisis DSC dilakukan untuk mengetahui efek termal dari proses fisik dan kimia. Berdasarkan penelitian asam usnat memiliki satu puncak endotermik tajam pada $205,637^{\circ} \mathrm{C}$ (menurut literatur $204,8^{\circ} \mathrm{C}$ ) dan N-metbylD-glucamine memiliki titik lebur $132,280^{\circ} \mathrm{C}$ (menurut literatur $128-132^{\circ} \mathrm{C}$ ). Gambar 2 menunjukkan termogram hasil kokristalisasi asam usnat -N-methyl-D-glucamine yang memiliki puncak lebur baru pada suhu lebih rendah yakni $94,139^{\circ} \mathrm{C}$. Hal ini diduga merupakan akibat terbentuknya campuran eutektik antara asam usnat dan N-methyl-Dglucamine. Pembentukan campuran ini dapat disebabkan oleh penurunan energi kisi kristal dan perubahan periodisitas kristal karena adanya interaksi fisika yang terjadi antara asam usnat dan N-methyl-D-glucamine. Analisis DSC pada penelitian ini menunjukkan hasil sama dengan penelitian kokristal asam usnat sebelumnya yang menggunakan metode grinding, yakni pada $176,5^{\circ} \mathrm{C}$ [13].

Morfologi kristal yang didapatkan dari hasil SEM
(Gambar 3) asam usnat berupa kristal berbentuk jarum, sesuai dengan penelitian sebelumnya yang menyatakan bahwa asam usnat berbentuk kristal jarum dan bewarna kuning [15]. Sedangkan N-methyl-D-glucamine menunjukkan morfologi berbentuk serbuk kristalin sebagaimana dinyatakan dalam penelitian sebelumnya bahwa N-methylD-glucamine berbentuk serbuk kristalin berwarna putihkekuningan [12]. Secara morfologi kokristal menunjukkan adanya perubahan bentuk (prisma) dan ukuran dibandingkan dengan zat penyusunnya. Hasil SEM ini menunjukkan bahwa terjadinya interaksi antara kedua zat yang mempengaruhi morfologi kristal masing-masing zat [16].

Analisis kualitatif dengan Spektroskopi FT-IR dilakukan untuk memperoleh informasi struktur dari senyawa. Spektroskopi IR sering digunakan untuk mengetahui adanya interaksi antara obat dengan koformer di dalam kokristal. Spektroskopi inframerah dapat mendeteksi formasi kokristal, hal ini terlihat dengan adanya ikatan hidrogen [17]. Terjadinya pergeseran bilangan gelombang diduga karena terjadinya ikatan hidrogen antara dua komponen. Ikatan hidrogen terjadi karena adanya gugus karbonil dari asam usnat berikatan dengan amina sekunder pada N-methyl-D-glucamine [18]. Hasil dari analisis FT-IR dapat dilihat pada Gambar 4 dan Tabel 3.

Tabe1 5. Hasil uji disolusi asam usnat dalam media air suling bebas $\mathrm{CO}_{2} 0,25 \% \mathrm{~b} / \mathrm{v}$ SLS, $(\mathrm{n}=3)$

\begin{tabular}{cccc}
\hline \multirow{2}{*}{ Waktu (menit) } & \multicolumn{3}{c}{ \% Rata-rata terdisolusi } \\
\cline { 2 - 4 } & Asam usnat murni & Campuran fisik & Kokristal \\
\hline 5 & $1,832 \pm 0,364$ & $4,437 \pm 0,504$ & $56,370 \pm 0,454$ \\
10 & $2,430 \pm 0,335$ & $13,705 \pm 0,761$ & $75,212 \pm 1,733$ \\
15 & $2,780 \pm 0,446$ & $19,580 \pm 1,150$ & $80,502 \pm 2,003$ \\
30 & $3,299 \pm 0,586$ & $29,226 \pm 2,395$ & $83,383 \pm 2,441$ \\
45 & $4,074 \pm 0,639$ & $31,740 \pm 0,983$ & $85,352 \pm 2,294$ \\
60 & $5,399 \pm 0,678$ & $33,007 \pm 0,179$ & $88,926 \pm 0,207$ \\
\hline
\end{tabular}


Tabel 6. Efisiensi disolusi asam usnat, campuran fisik dan kokristal

\begin{tabular}{cccc}
\hline & \multicolumn{3}{c}{ Efisiensi disolusi (\%), $\mathbf{N = 3}$} \\
\cline { 2 - 4 } & Asam usnat & Campuran fisik & Kokristal \\
\hline Rata-rata efisiensi disolusi & $3,337 \pm 0,465$ & $24,142 \pm 0,672$ & $77,682 \pm 1,510$ \\
Peningkatan efisiensi disolusi & - & 7,235 & 23,279 \\
\hline
\end{tabular}

Data ini mendukung hasil analisis difraksi sinar-X, DSC, dan SEM bahwa pada kokristal terdapat pergeseran pita absorpsi yang menunjukkan terjadi perubahan struktur kristal asam usnat.

Uji kelarutan dilakukan menggunakan pelarut air suling bebas $\mathrm{CO}_{2}$. Panjang gelombang serapan maksimum asam usnat dalam air suling bebas $\mathrm{CO}_{2}$ diukur menggunakan spektrofotometer UV-Vis dan didapatkan serapan maksimum pada panjang gelombang $288 \mathrm{~nm}$. Kurva kalibrasi menunjukkan hubungan linear antara konsentrasi dan serapan asam usnat dalam pelarut dengan persamaan regresi $y=0,0714 x+0,0028$ dengan nilai $R^{2}$ adalah 0,998. Pengujian kelarutan dilakukan selama 24 jam pada suhu $25^{\circ} \mathrm{C}$ sesuai dengan standar yang sering digunakan [19]. Rata-rata kelarutan asam usnat murni, campuran fisik dan kokristal (mg/100 mL) yang diperoleh adalah 0,256 $\pm 0,002,3,654 \pm 0,210$, dan 6,338 $\pm 0,101$ (Tabel 4).

Uji disolusi dilakukan terhadap asam usnat murni, campuran fisik, dan kokristal. Panjang gelombang serapan maksimum asam usnat dalam air suling bebas $\mathrm{CO}_{2}, 0,25 \%$ (b/v) SLS diukur menggunakan spektrofotometer UVVis dan didapatkan serapan maksimum pada panjang gelombang 289 nm. Kurva kalibrasi menunjukkan hubungan linear antara konsentrasi dan serapan asam usnat dalam pelarut dengan persamaan regresi $\mathrm{y}=0,0714 \mathrm{x}$ + 0,0268 dengan nilai R2 adalah 0,999. Berdasarkan hasil uji disolusi pada Tabel 5 didapatkan rata-rata \% asam usnat yang terdisolusi pada menit ke-60 dalam asam usnat murni, campuran fisik, dan kokristal berturut-turut adalah 5,399 $\pm 0,678,33,007 \pm 0,179$, dan 88,926 $\pm 0,207$. Peningkatan laju disolusi senyawa obat sukar larut dalam air merupakan pendekatan yang sangat tepat untuk memperbaiki absorpsi senyawa obat tersebut dalam saluran pencernaan melalui rute pemberian secara oral [20].

Perhitungan rata-rata efisiensi disolusi asam usnat (Tabel 6) diperoleh dari luas daerah di bawah kurva adalah asam usnat murni $=3,337 \pm 0,465 \%$, campuran fisik $=$ $24,142 \pm 0,672 \%$, dan kokristal $=77,682 \pm 1,510 \%$. Hal ini menunjukkan terjadinya peningkatan jumlah asam usnat terdisolusi dari pembentukan campuran fisik sebesar 7 kali dan kokristal sebesar 23 kali dibandingkan asam usnat murni. Peningkatan disolusi kokristal diduga terjadi karena terbentuknya energi kisi yang lebih rendah seperti yang terjadi pada proses peningkatan kelarutan. Kokristalisasi dapat meningkatkan kelarutan dan laju disolusi karena

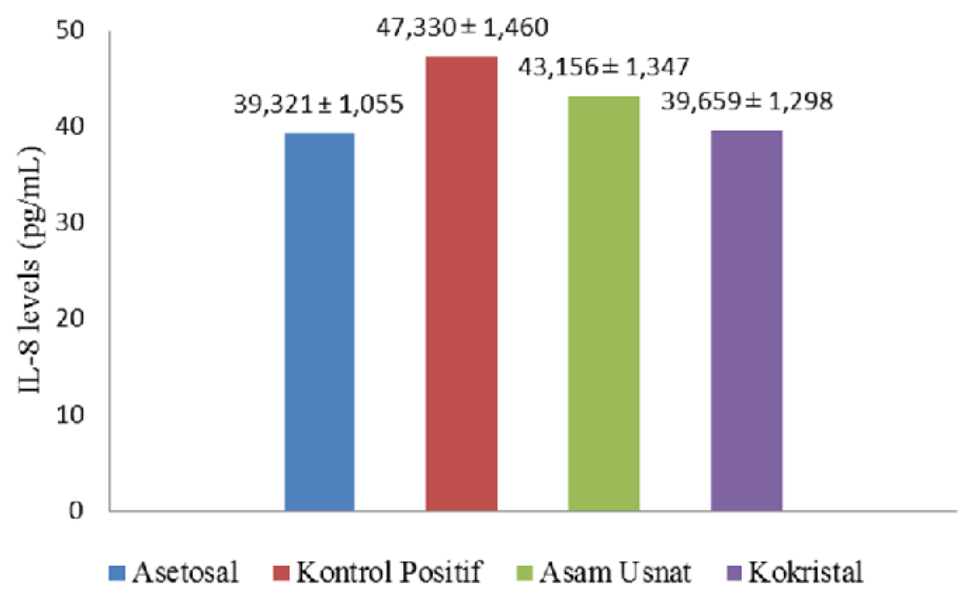

Gambar 5. Diagram perbandingan kadar IL-8 tikus inflamasi $(N=5)$ 
kokristal memiliki profil fisikokimia yang berbeda. Asam usnat-N-methyl-D-glucamine terikat bersama dalam kisi kristal melalui interaksi nonkovalen yaitu ikatan hidrogen [8].

Kadar rata-rata IL-8 yang diperoleh menunjukkan bahwa kokristal asam usnat dapat menurunkan kadar IL-8 tikus inflamasi jika dibandingkan dengan kontrol positif. Berbeda dengan kokristalnya asam usnat murni hanya menunjukkan sedikit penurunan kadar IL-8 (Gambar 5). Aktivitas kokristal asam usnat yang lebih baik dalam menekan kadar IL-8, ini mendukung hasil uji kelarutan dan uji disolusi kokristal asam usnat- $\mathrm{N}$-methyl-D-glucamine yang dilakukan sebelumnya. Pada saat proses terjadinya radang, konsentrasi sitokin proinflamasi seperti TNF- $\alpha$, IL-1, IL6, IL-8 mengalami peningkatan. Kokristal asam usnat yang memiliki aktivitas sebagai antiinflamasi dapat menekan sitokin proinflamasi sehingga peradangan berkurang.

\section{Kesimpulan}

Hasil karakterisasi dengan difraksi sinar-X menunjukkan terbentuknya fase kristalin baru atau kokristal dari asam usnat-N-methyl-D-glucamine dengan metode penguapan pelarut yang didukung oleh hasil DSC, FT-IR, dan SEM. Fase kristalin baru yang terbentuk dari asam usnat dan N-methyl-D-glucamine dapat meningkatkan kelarutan dari asam usnat yaitu sebesar 24 kali dan efisiensi disolusi asam usnat sebesar 23 kali. Kokristal asam usnat dan N-methyl-D-glucamine dapat menurunkan kadar IL-8 pada tikus inflamasi yang setara dengan aktivitas antiinflamasi asetosal $(\mathrm{P}<0,05)$.

\section{Referensi}

[1]. Fitriani L, Afriyanti I, Afriyani A, Ismed F, Zaini E. Solid Dispersion of Usnic acid-HPMC 2910 Prepared by Spray drying and Freeze drying Techniques. Orient J Chem. 2018;34(4):2083-8. https://doi. org/10.13005/ojc/3404048

[2]. Araújo AAS, de Melo MGD, Rabelo TK, Nunes PS, Santos SL, Serafini $M R$, et al. Review of the biological properties and toxicity of usnic acid. Nat Prod Res. 2015;29(23):2167-80. https://doi.org/10.1080/ $\underline{14786419.2015 .1007455}$
[3]. O'Neil MJ. The Merck Index- An Encyclopedia of Chemicals, Drugs, and Biologicals (Vol. 13th Edition). Whitehouse Station (NJ): Merck and $\mathrm{Co} ; 2001$

[4]. Cocchietto M, Skert N, Nimis P, Sava G. A review on usnic acid, an interesting natural compound. Naturwissenschaften. 2002. https:// doi.org/10.1007/s00114-002-0305-3

[5]. Sangster J. LogKow Databank. Canada, Sangster Res. Lab; 1993.

[6]. Bačkor M, Hudá J, Repčák M, Ziegler§ W, Bačkorová M. The Influence of pH and Lichen Metabolites (Vulpinic Acid and (+) Usnic Acid) on the Growth of the Lichen Photobiont Trebouxia Irregularis. Lichenol. 1992;30(6):577-82. https://doi.org/10.1006/lich.1998.0166

[7]. Song Y, Wang L, Yang P, Wenslow RM, Tan B, Zhang H, et al. Physicochemical Characterization of Felodipine-Kollidon VA64 Amorphous Solid Dispersions Prepared by Hot-Melt Extrusion. J Pharm Sci. 2013;102(6):1915-23. https://doi.org/10.1002/ ips.23538

[8]. Jones W, Motherwell WDS, Trask A V. Pharmaceutical Cocrystals: An Emerging Approach to Physical Property Enhancement. MRS Bull. 2006;31(11):875-9. https://doi.org/10.1557/mrs2006.206

[9]. Pratiwi W. Preparasi Tablet Kokristal Ibuprofen - Nikotinamida dan Evaluasi Laju Disolusinya [skripsi]. Padang: Fakultas Farmasi Universitas Andalas; 2013.

[10]. Utami RD. Pembentukan Kokristal Asam Usnat dan 4- Aminopiridin dengan Metode Solvent Drop Grinding [skripsi]. Padang: Fakultas Farmasi Universitas Andalas; 2017.

[11]. Nisak RK. Pengaruh Pembentukan Kokristal Asam Usnat-Piperazin dengan Metode Solvent Drop Grinding terhadap Kelarutan dan Profil Disolusi [skripsi]. Padang: Fakultas Farmasi Universitas Andalas; 2017

[12]. Rowe RC, Sheskey PJ, Quinn ME. Handbook of pharmaceutical excipient, (6nd Ed). London: The Pharmaceutical Press; 2009.

[13]. Lailaturrahmi. Pembentukan Kokristal Asam Usnat dan N-methyl-Dglucamine dengan Metode Solvent Drop Grinding [skripsi]. Padang: Fakultas Farmasi Universitas Andalas; 2018.

[14]. Davis RE, Lorimer KA, Wilkowski MA, Rivers JH, Wheeler KA, Bowers J. Studies of phase relationships in cocrystal systems. Cryst Supramol Chem. 2004;17;39:41-61.

[15]. Fanun M. Colloids in Drug Delivery. CRC Press: USA; 2010.

[16]. Alatas F, Soewandhi SN, Sasongko L, Ismunandar, Uekusa H. Cocrystal formation between didanosine and two aromatic acids. Int J Pharm Pharm Sci. 2013;5(Suppl 3):275-80.

[17]. Schultheiss N, Newman A. Pharmaceutical Cocrystals and Their Physicochemical Properties. Cryst Growth Des. 2009;9(6):2950-67. https://doi.org/10.1021/cg900129f

[18]. Mirza S, Miroshnyk I, Heinämäki J, Yliruusi J. Co-crystals: An emerging approach for enhancing properties of pharmaceutical solids. Dosis. 2008;24(2):90-6.

[19]. Glomme A, März J, Dressman JB. Comparison of a Miniaturized Shake-Flask Solubility Method with Automated Potentiometric Acid/ Base Titrations and Calculated Solubilities. J Pharm Sci. 2005;94(1):116. https://doi.org/10.1002/jps.20212

[20]. Chono S, Takeda E, Seki T, Morimoto K. Enhancement of the dissolution rate and gastrointestinal absorption of pranlukast as a model poorly water-soluble drug by grinding with gelatin. Int J Pharm. 2008;347(1-2):71-8. https://doi.org/10.1016/j. ijpharm.2007.06.037 